\title{
VARIATION IN $\beta$-GLUCAN, PROTEIN AND FAT CONCENTRATION OF OATS CREATED IN LATVIA
}

\author{
Vita Šterna", Sanita Zute, and Zaiga Vicupe \\ Stende Research Centre, Institute of Agricultural Resources and Economics „Dižzemes”, Dižstende, Libagi civil parish, \\ Talsi Municipality, LV-3258, LATVIA \\ \# Corresponding author: vita.sterna@arei.Iv
}

Communicated by Inga Ciproviča

\begin{abstract}
Consumption of dietary fibre has potential in improving nutrition and health. For further breeding of oats, it is necessary to increase knowledge on variation in the content of fibre and bioactive components in oats. Therefore, the aim of the present investigation was to study the extent of variation in $\beta$-glucan concentration of oats grown in Latvia and to evaluate association of $\beta$-glucan concentration with protein and fat concentration in newly created oat breeding lines. In 2015 and 2016, concentration of protein, fat, and $\beta$-glucan in grain of hulled oat varieties 'Laima', 'Peppi', and ten breeding lines was determined. The obtained results showed a wide range of fat concentration among varieties, with a range from 5.9 to $8.3 \%$. The concentration of $\beta$-glucan ranged from 1.8 to $3.6 \%$ depending on the year. The $\beta$-glucan concentration had medium close positive correlation with lipid and weak significant positive correlation with protein concentration, which significantly differed among genotypes.
\end{abstract}

Key words: grains, protein, $\beta$-glucans, varieties.

\section{INTRODUCTION}

Consumption of dietary fibre has potential in improving nutrition and health (Havrlentova et al., 2011; Arendt and Zannini, 2013). Oat (Avena sativa L.) is a well-known crop in the temperate climate. It is recognised throughout the world as a healthy food containing significant amounts of soluble dietary fibre, $\beta$-glucans, fat-soluble vitamin $\mathrm{E}$ and polyunsaturated fatty acids. The health effects of oats have been primarily attributed to the dietary fibre fraction, particularly $\beta$-glucans, which decrease and stabilise the levels of serum glucose and insulin (Wood et al., 1990; Jenkins et al., 2002) and decrease the level of blood cholesterol (Pomeroy et al., 2001, Kerckhoffs et al., 2002, Kelly et al., 2007). The addition of oats adds more nutritious components to the food (Wang et al., 2007).

Although cultivar differences in the parameters directing oat breeding and cultivation such as seed size, yield, lodging resistence, and nutritional attributes (for example, protein, and lipid concentration) are widely studied (Arendt and Zannini, 2013; Biel et al., 2009), study of $\beta$-glucan concentration, particularly in relation to other oat components, is insufficient. Earlier reports on an association between protein and $\beta$-glucan concentration are controversial. Saastamoinen et al. (1992) in a two-year study found a negative correlation for Northern genotypes, while Peterson et al. (1995) reported a tendency to positive correlations. In gen- eral, the studies show that genotypes differ in their response (Welch, 1995). For further breeding of oats with the aim to promote human health, it is necessary to increase knowledge on variation in $\beta$-glucan concentration of oats, in relation to protein and fat concentration in the new oat genotypes, considering also other important properties for food production. Old and new types need to be characterised on a broader scale, including needs of consumers and producers.

The aim of the present study was to determine the $\beta$-glucan concentration of oats grown in Latvia, in relation to protein and fat concentration in the newly created oat breeding lines.

\section{MATERIALS AND METHODS}

The study was conducted at the Institute of Agricultural Resources and Economics, Stende Research Centre from 2015 to 2016. The study material consisted of 12 oat genotypes: VP2, VP3, VP4, VP5, VP6, VP8, VP9, VP10, VP11, VP12 as a new type and two varieties commonly used in production by millers - 'Laima', a widely grown variety in Latvia, and 'Peppi' from Finland as a preferred imported variety. The experiment was set up as a split-plot design in four replications, to exclude the effect of environmental conditions among the varieties. The characteristic environmental conditions in 2015 and 2016 years are given in Table 1. 
Table 1

CHARACTERISTIC ENVIRONMENTAL CONDITIONS IN 2015 AND 2016

\begin{tabular}{l|c|c|c|c|c|c|c}
\hline \multirow{2}{*}{} & \multicolumn{2}{|c|}{$\begin{array}{c}\text { Temperature, } \\
{ }^{\circ} \mathrm{C}\end{array}$} & \multicolumn{2}{c|}{$\begin{array}{c}\text { Precipitation, } \\
\mathrm{mm}\end{array}$} & \multicolumn{3}{c}{ Soil } \\
\cline { 2 - 8 } & 2015 & 2016 & 2015 & 2016 & Trait & 2015 & 2016 \\
\hline April & 5.6 & 5.8 & 98.5 & 37.0 & $\mathrm{pH}$ & 5.6 & 5.6 \\
May & 9.8 & 13.3 & 65.9 & 61.0 & $\begin{array}{c}\text { Organic } \\
\text { matter, \% }\end{array}$ & 2.6 & 1.7 \\
June & 13.5 & 15.6 & 50.5 & 92.5 & $\begin{array}{c}\mathrm{P}_{2} \mathrm{O}_{5}, \\
\mathrm{mg}^{-1} \mathrm{~kg}^{-1}\end{array}$ & 180 & 174 \\
July & 15.9 & 17.2 & 75.5 & 91.7 & $\begin{array}{c}\mathrm{K}_{2} \mathrm{O}^{-1} \\
\mathrm{mg}^{2} \mathrm{~kg}^{-1}\end{array}$ & 117 & 162 \\
August & 17.5 & 16.0 & 26.6 & 110.4 & & &
\end{tabular}

Mean samples from each of the four replications $(0.5 \mathrm{~kg})$ were taken for laboratory testing. Covered grains were dehulled mechanically. Weight, and protein, lipid and $\beta$-glucan concentration in the studied samples $(\mathrm{n}=92)$ were determined using an automatic grain analyser Infratec Analyser 1241.

The obtained results were statistically processed using methods of descriptive statistics and analysis of variance using the SPSS 20 programme package. Statistical significance was declared at $p<0.05$ or at $p<0.01$.

\section{RESULTS}

The results of analysed protein, lipids and $\beta$-glucans concentration in grain of hulled oat varieties and breeding lines in 2015 and 2016 years are summarised in Figure 1. The results of investigation showed that the concentration of protein in oat grain depending on genotype ranged from $10.4 \%$ to $14.9 \%$, and the richest were grains of the variety 'Peppi'. The concentration of protein significantly differed by genotype $(p<0.01)$ and year $(p<0.05)$.

The concentration of lipids in oat grain was from $5.4 \%$ to $7.9 \%$ and it significantly differed by genotypes $(p<0.05)$. The highest lipid concentration was found in grain of variety 'Laima' $7.65 \pm 0.29 \%$.

The highest $\beta$-glucan concentration of grain was in varieties 'Laima' and 'Peppi' and breeding lines VP4 and VP5, with average $\beta$-glucan concentrations $3.24 \pm 0.29 \%, 2.98 \pm$ $0.08 \%, 2.75 \pm 0.09 \%$, and $2.75 \pm 0.09 \%$, respectively. The $\beta$-glucan concentration significantly differed by genotypes $(p<0.05)$, but not between years $(p>0.05)$.

Comparison of correlation between grain components in the two years of study is shown in Figure 2. $\beta$-glucan concentration had weak positive correlation with protein concentration in most genotypes ('Laima', VP2, VP3, VP7, VP8, VP9, VP12), and strong positive correlation $(\mathrm{r}=0.761)$ for genotype VP5; for grain of genotypes VP4 and VP11 there was a strong negative correlation $(r=-0.881$ and $r=$ -0.837 , respectively). Figure 2 shows that the correlation (all genotypes together) between $\beta$-glucan and protein con-

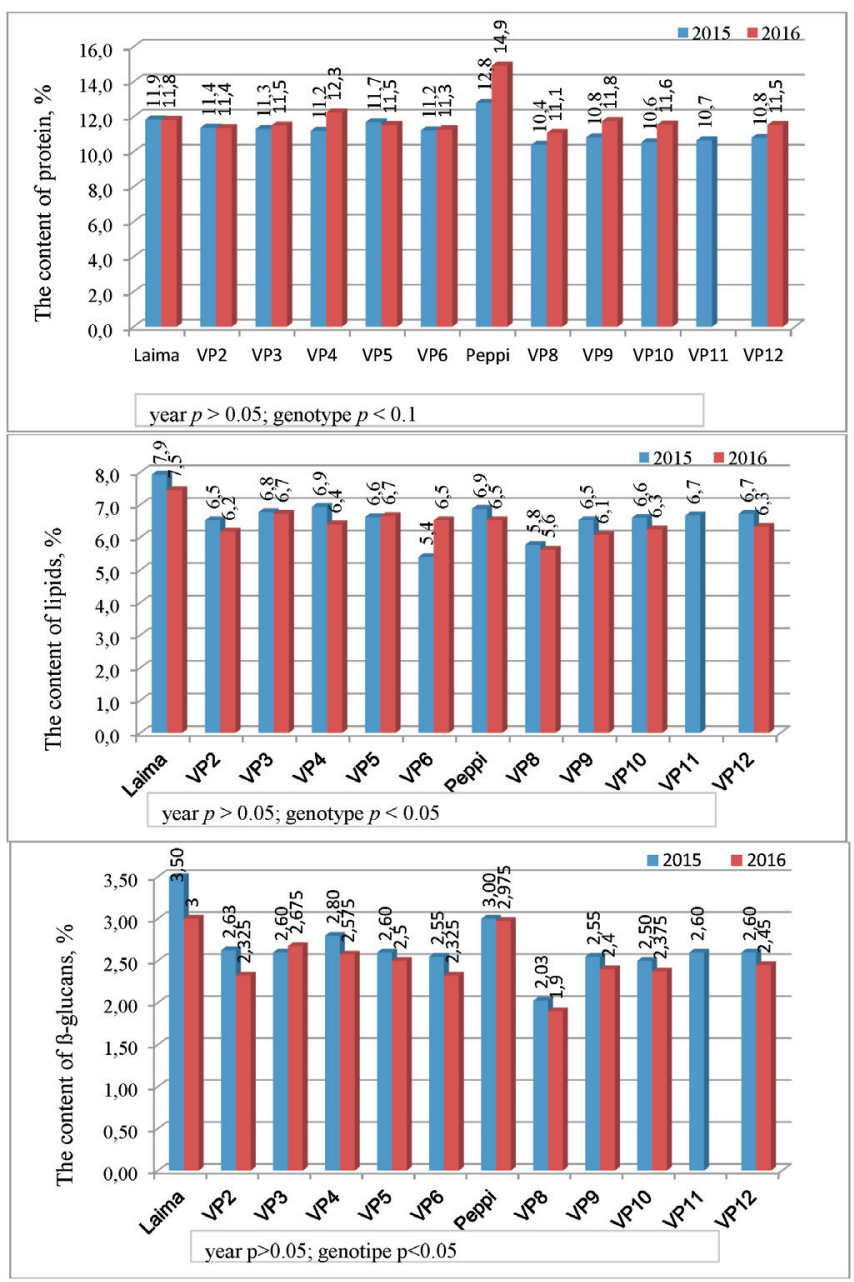

Fig. 1. Comparison of protein, lipid and $\beta$-glucan concentration between years.

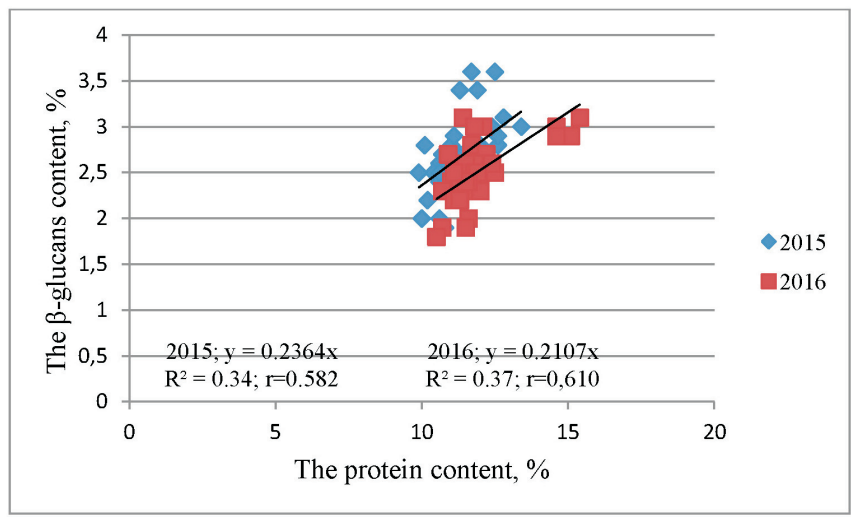

Fig. 2. Correlation between protein and $\beta$-glucan concentration in oat grain.

centration was weakly positive and significant in both years

Correlation between lipid and $\beta$-glucan concentration in grain of oat varieties and breeding lines is shown in Figure 3. $\beta$-glucan concentration had positive correlation with lipid concentration of oat grain (all genotypes together). Weak positive correlation occurred for genotypes VP3, VP4, VP5, VP6, VP8, variety 'Peppi', medium correlation for breeding lines VP9, VP10, VP11, VP12, and strong correlation for 'Laima' $(r=0.741)$ and VP2 $(r=0.719)$. 


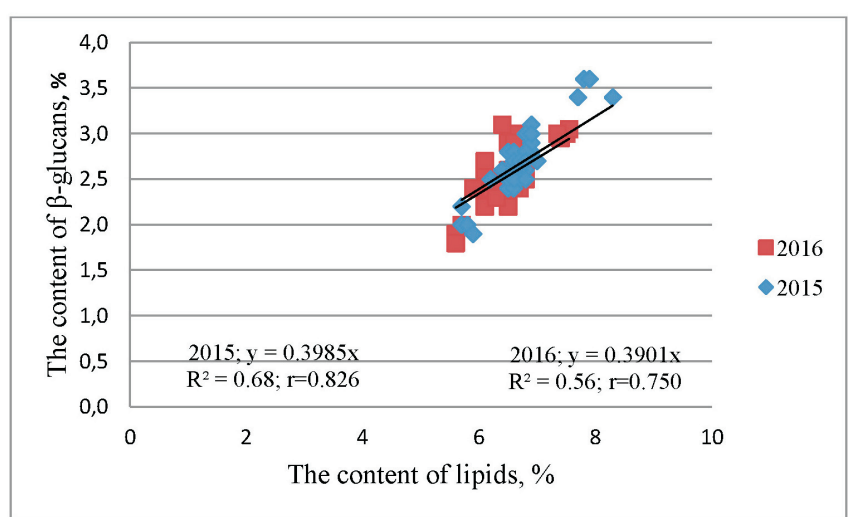

Fig. 3. Correlation between lipids and $\beta$-glucans concentration in oat grain.

\section{DISCUSSION}

The results of evaluated chemical composition of oat grains presented in this paper are similar with those of other studies, where protein concentration for husked oat was 115.0 $\mathrm{g} \cdot \mathrm{kg}^{-1}$ (Biel et al., 2009), $104.0 \mathrm{~g} \cdot \mathrm{kg}^{-1}$ (Tobiasz-Salach et al., 2016), 90-96 g. $\mathrm{kg}^{-1}$ (Givens et al., 2004) and $15.9 \%$ (Asp et al., 1992). Higher protein concentration was observed in 2016 than in 2015, particularly for genotypes VP4, VP8, VP9, VP10, VP12, and variety 'Peppe' (Fig. 1). The lipid concentration of tested oat grains varied from 5.8 to $7.9 \%$ in 2015 , and from 5.6 to $7.5 \%$ in 2016 . According to previous reports, the lipid concentration in oat grains range is from 3.1 to $11.8 \%$ (Zhou et al., 1999); moreover, the naked oat form is characterised by higher fat concentration $(7.4-7.7 \%)$ in the grain than in the hulled form 3.7-4.4\% (Tobiasz-Salach et al., 2016). According to our previous investigations, concentration of lipids in husked oat grains was $4.0-5.67 \%$ in 2013 , in variety 'Laima' $5.65 \%$ (Sterna et al., 2014). In the present study, the average concentration of lipids in grain of variety 'Laima' was 7.9\% (2015) and 7.5\% (2016). All breeding lines had $0.1-0.4 \%$ less lipid content in 2016. Givens et al. (2004) concluded that lipid concentration in oat is strongly dependent on meteorological conditions of the sowing year. In our study period, there was much more precipitation in June, July, and August of 2016 than in 2015 in Stende (Table 1).

The concentration of $\beta$-glucans of oat grains samples ranged from $2.9 \%$ to $3.6 \%$, which was lower than we observed in a previous study, where average concentration of $\beta$-glucan for husked oat varieties ranged from 3.79\% ('Laima') to $3.85 \%$ ('Stendes Dārta') (Brunava et al., 2014). Generally, $\beta$-glucan concentration in grain in 2016 was $0.1-0.3 \%$ less than in 2015 , excepting for the variety 'Laima', where $\beta$-glucan concentration was $0.5 \%$ less than in 2015. This can be explained by much more precipitation in June, July and August. Saastomoinen et al. (2004) reported significant differences in average $\beta$-glucans concentration of oats between years. For example, variety 'Kolbu' had significantly lower $\beta$-glucan concentration during a cool rainy weather in 1998 (3.44\% of dry matter), than in the warm years 1997 (4.38\% of dry matter) and 1999 (4.02\% of dry matter). Studies have shown that environ- ment, species and origin greatly influence endosperm and cell wall development and affect the accumulation of $\beta$-glucans (Fastnaught et al., 1996). Species has the greatest effect on $\beta$-glucan concentration, followed by origin and year (Saastomoinen et al., 2004; Hu et al., 2014).

The relationship between protein and $\beta$-glucan concentration is controversial. The relationship between protein and $\beta$-glucan concentration in this study generally showed a tendency to positive correlation (Fig. 2), but for genotypes VP4 and VP11 there was a strong negative correlation. This indicates that genotypes differ in their responses, as previously reported (Welch, 1995). Oat fibre is the most variable constituent, with more than a five-fold variation across species. The distribution of each constituent between botanical parts of the oat kernel is irregular. Consequently, considerable differences may be observed between gross chemical composition of total grains.

The correlation between lipid and $\beta$-glucan concentration in this study was positive in all varieties and breeding lines and, as a whole, medium high (Fig. 3). These results are in agreement with previous work (Asp et al. 1992) that showed $\beta$-glucans concentration to be significantly positively correlated with insoluble and total dietary fibre as well as fat concentration.

\section{CONCLUSION}

It is concluded that $\beta$-glucan concentration in oat grains varied from $2.9 \%$ to $3.6 \%$. The highest $\beta$-glucan concentration among new breeding lines occurred in VP4 and VP5. Furthermore, there was a strong positive correlation with protein and lipid concentration in oat grains of breeding line VP5.

\section{ACKNOWLEDGMENTS}

Publication and dissemination of research results has been made due to the support of National Research Programme AgroBioRes.

\section{REFERENCES}

Arendt, E. K., Zannini, E. (2013). Cereal Grains for the Food and Beverage Industries. Cambridge: Woodhead Publishing. 485.

Asp, N. G., Mattsson, B., Onning, G. (1992) Variation in dietary fibre, $\beta$-glucan, starch, protein, fat and hull content of oats grown in Sweden 1987-1989. Eur. J. Clin. Nutr. 46, 31-37.

Biel, W., Bobko, K., Maciorowski, R. (2009). Chemical composition and nutritive value of husked and naked oats grain. J. Cereal Sci., 49, 413-418.

Brunava, L., Alsina, I., Zute, S., Sterna, V., Vicupe, Z. (2014). Some chemical yield and quality properties of domestic oat cultivars. In: Proceedings of the $9^{\text {th }}$ Baltic Conference on Food Science and Technology "Food for Consumer Well-being” FOODBALT 2014, pp. 72-76.

Givens, D. I., Davies, T. W., Laverick, R. M. (2004). Effect of variety, nitrogen fertilizer and various agronomic factors on the nutritional value of husked and naked oats grain. Animal Feed Sci. Technol., 113, 169-181. 
Fastnaught, C. E., Berglund, P. T., Helm, E. T., Fox, G. J. (1996). Genetic and environmental variation in beta-glucan content and quality parameters of barley for food. Crop Sci., 36, 941-946.

Havrlentova, M., Petrulakova, Z., Burgarova, A., Gago, F., Hlinkova, A., Sturdik, E. (2011). Cereal $\beta$-glucans and their significance for the preparation of functional food. Review. Czech J. Food Sci., 29 (1), 1-4.

Hu, X. Z., Zheng, J. M., Li, Xu, C., Zhao, Q. (2014). Chemical composition and sensory characteristics of oat flakes: A comparative study of naked oat flakes from China and hulled oat flakes from western countries. J. Cereal Sci., 60, 279-301.

Jenkins, A. L., Jenkins D. J. A., Zdravkovic, U., Wursch, P., Vuksan, V. (2002). Depression of the glycemic index by high levels of b-glucan fiber in two functional foods tested in type 2 diabetes. Eur. J. Clin. Nutr., 56, 622-628.

Kelly, S. A. M., Summerbell, C. D., Brynes, A., Whittaker, V., Frost, G. (2007). Wholegrain cereals for coronary heart disease. Cochrane Database of Systematic Reviews, 1, 1-66.

Kerckhoffs, D. A. J. M., Brouns, F., Hornstra, G., Mensink, R. P. (2002). Effects on the human serum lipoprotein profile of $\beta$-glucan, soy protein and isoflavones, plant sterols and stanols, garlic and tocotrienols. J. Nutr., 132, 2494-2505.

Peterson, D. M., Wesenberg, D., Burrup, D. (1995). $\beta$-glucan content and its relationship to agronomic characteristics in elite oat germplasm. Crop Sci., 35, 965-970.
Pomeroy, S., Tupper, R., Cehun-Aders, M., Nestel, P. (2001) Oat $\beta$-glucan lowers total and LDL-cholesterol. Austr. J. Nutr. Dietetics, 58, 51-55.

Saastomoinen, M., Kontturi, M., Tuuri, H. Niskanen, M., Kangas, A. (2004). $\beta$-Glucan contents of groats of different oat cultivars in official variety, in organic cultivation, and in nitrogen ferilization trials in Finland. Agr. Food Sci., 13, 68-79.

Saastamoinen, M., Plaami, S., Kumpulainen, J. (1992). Genetic and environmental variation in $\beta$-glucan content of oats cultivated or tested in Finland. J. Cereal Sci., 16, 279-290.

Sterna, V., Zute, S., Brunava, L., Vicupe, Z. (2014). Lipid composition of oat grain grown in Latvia. In: Proceedings of the $9^{\text {th }}$ Baltic Conference on Food Science and Technology "Food for Consumer Well-being" FOODBALT 2014, pp. 77-79.

Tobiasz-Salach, R., Bobrecka-Jamro, D., Pyrek, E., Buczek, J. (2016). Response of hulled and naked oat to foliar fertilization. Acta Sci. Pol. Agricult., 15 (2), 77-78.

Wang, R. H., Koutinas, Campbell, G. M., (2007). Effect of pearling on dry processing of oats. J. Food Eng., 82, 369-376.

Welch, R. W. (1995). The Oat Crop: Production and Utilization. London, Chapman \& Hall. 584 pp. (at p. 516).

Wood, P. J., Braten, J. T., Scott, F. W., Riedel, D., Poste, L. M. (1990). Comparison of viscous properties of oat and guar gum and the effects of these and oat bran on glycemic index. J. Agr. Food Chem., 38, 753-757.

Zhou, M. X., Robards, K., Glennie-Holmes, M., Helliwell, S. (1999). Oat lipids. J. Amer. Oil Chem. Soc., 79, 585-592.

Received 5 December 2016

Accepted in the final form 9 December 2017

\section{$\beta$ —GLIKĀNA, PROTEĪNA UN TAUKU SATURA MAINĪBA LATVIJĀ SELEKCIONĒTAJĀS AUZĀS}

Cilvēka veselības un uztura uzlabošanā diētisko šķiedrvielu patēriṇam ir liels potenciāls. Turklāt auzu šķirṇu selekcionēšanā palielinās nepieciešamība izpētìt šķiedrvielu un bioaktīvo komponentu mainību auzās. Tādēl, šī pētìjuma mērḳis bija noteikt $\beta$-glikāna saturu Latvijā audzētajās auzu škirnēs un novērtēt sakarības starp $\beta$-glikānu, proteīnu un tauku saturu jaunajās selekcionētajās genenētiskajās līnijās. Proteīna, tauku un $\beta$-glikāna saturs tika analizēts 2015. un 2016. gadā plēkšņgraudu auzu škirņu 'Laima' un 'Peppi' un desmit selekcionēto auzu līniju graudos. Iegūtie rezultāti liecina, ka tauku saturs noteikts no 5.9 līdz 8.3\%, $\beta$-glikāns no 1.8 līdz 3.6\%, atkarībā no audzēšanas gada un šķirnes. Noteikta vidēji cieša $\beta$-glikāna korelācija ar tauku saturu un vāja pozitīva $\beta$-glikāna korelācija ar proteīna saturu. 